\title{
Glucagon Levels and Metabolic Effects in Fasting Man
}

\author{
Errol B. Marliss, Thomas T. Aoki, Roger H. Unger, J. Stuart Soeldner, \\ and George F. Cahill, Jr. \\ From the Department of Medicine, Harvard Medical School and the Peter Bent \\ Brigham Hospital, the Elliott P. Joslin Diabetes Foundation, Inc., Boston, Mas- \\ sachusetts 02215, the Department of Internal Medicine, the University of Texas \\ Southwestern Medical School at Dallas, and the V.A. Hospital, \\ Dallas, Texas 75216
}

A B S T RACT The role of glucagon in the metabolic adaptation to prolonged fasting in man has been examined. Plasma immunoreactive glucagon was determined during 6-wk fasts and during infusion of exogenous glucagon using an assay which minimized nonpancreatic immunoreactivity.

Plasma glucagon concentrations rose twofold to a peak on the 3rd day of fasting and then declined thereafter to a level maintained at or above postabsorptive. Insulin concentration declined to a plateau by the 3 rd day. Thus a persisting altered relationship of glucagon and insulin concentrations characterized the fasted state. A synergism of low insulin and relative or absolute elevation of glucagon levels is viewed as a hormonal mechanism controlling the rate of hepatic substrate extraction for gluconeogenesis.

Glucagon was infused systemically into 4-6-wk fasted subjects at three dose levels. A marked sensitivity of individual plasma free amino acids to the induced elevations of plasma glucagon within the physiologic range was demonstrated. At higher concentrations, equivalent to those present in the portal vein, stimulation of hepatic gluconeogenesis occurred, and the effects on glucose, insulin, and growth hormone levels and on ketone metabolism were induced.

\section{INTRODUCTION}

Although glucagon is essential to metabolic homeostasis in some species $(1,2)$, a physiologic role in man has not

These data have been presented in part at the meeting of the American Society for Clinical Investigation, Atlantic City, N. J., 3 May 1970.

Dr. Marliss is recipient of a Medical Research Council of Canada Fellowship, and Dr. Aoki of U. S. Public Health Service Special Postdoctoral Fellowship 1 FO3 AM43067 01.

Received for publication 11 June 1970 and in revised form $27 J_{u l y} 1970$. been defined. Glucagon secretion is responsive to induced hypoglycemia (3) and to infusion or ingestion of large loads of amino acids (4), but these are not standard challenges within the physiologic setting of alternating meal consumption and fasting. Since man maintains his blood glucose concentration mainly by gluconeogenesis (5), the glycogenolytic effect of glucagon may not be a primary function, except in "emergency" situations. Unger and colleagues have suggested that the relative levels of insulin and glucagon are important in fasting and after amino acid challenge. In fasting they demonstrated elevated plasma levels of immunoreactive glucagon in the presence of lowered insulin levels and have suggested a synergistic effect on hepatic glucose release (6). In the latter situation during protein or amino acid challenge, they have proposed that the parallel increases of glucagon with increasing insulin levels prevent the hypoglycemia that would otherwise occur if insulin levels alone were to rise (7).

It has been shown that man, when fasted, reaches a near steady state with respect to protein, fat, and carbohydrate metabolism by 3 wk (8). Gluconeogenesis from protein, though initially increased, diminishes to a plateau by this time, as the adaptation of brain to ketone body oxidation reduces the glucose requirement of the body. Any induced hormonal alteration at such a time might be expected to influence this metabolic adjustment in a manner which provides insight into the relative importance of the physiological effects of the hormone to fuel homeostasis. Furthermore, the availability of hormonal assays now permits quantification of the levels of hormone achieved during its administration and permits correlation with known physiological levels.

Presently available immuno- and bioassays demonstrate that pancreatic glucagon circulates in extremely low concentrations $(7,9)$. Metabolic responses in most previous studies have therefore been a result of pharmacologic 
TABLE I

Clinical Data

\begin{tabular}{|c|c|c|c|c|c|c|c|c|}
\hline \multirow{3}{*}{ Initials } & \multirow{3}{*}{$\frac{\text { Age }}{y r}$} & \multirow{3}{*}{ Sex } & \multirow{3}{*}{$\frac{\text { Height }}{\mathrm{cm}}$} & \multicolumn{3}{|c|}{ Weight } & \multirow{2}{*}{\multicolumn{2}{|c|}{$\begin{array}{l}\text { Deviation of } \\
\text { initial weight } \\
\text { from population } \\
\text { ideal weight* }\end{array}$}} \\
\hline & & & & Initial & Final & Difference & & \\
\hline & & & & & kg & & $\%$ & $K_{\ddagger}^{\ddagger}$ \\
\hline $\mathrm{RB}$ & 40 & $\mathrm{~F}$ & 175 & 152.7 & 133.6 & 19.1 & 116 & 1.42 \\
\hline DB & 37 & M & 183 & 160.8 & 138.8 & 22.0 & 100 & 1.30 \\
\hline $\mathrm{SC}$ & 42 & $\mathbf{M}$ & 180 & 117.7 & 97.6 & 20.1 & 48 & 1.40 \\
\hline $\mathrm{J} \mathrm{Ca}$ & 51 & $F$ & 171 & 122.7 & 102.3 & 20.4 & 66 & 1.09 \\
\hline $\mathrm{J} \mathrm{Co}$ & 38 & $\mathbf{M}$ & 180 & 107.2 & 86.9 & 20.3 & 46 & 1.48 \\
\hline $\mathrm{PC}$ & 27 & $\mathrm{~F}$ & 165 & 93.3 & 76.8 & 16.5 & 56 & 1.89 \\
\hline FD & 30 & $\mathbf{M}$ & 173 & 114.5 & 93.0 & 21.5 & 66 & 1.02 \\
\hline LD & 21 & $\mathrm{~F}$ & 175 & 102.1 & 84.1 & 18.0 & 56 & 2.03 \\
\hline $\mathrm{FF}$ & 38 & $\mathbf{M}$ & 183 & 130.0 & 104.7 & 25.3 & 60 & 1.82 \\
\hline MH & 35 & $F$ & 155 & 95.4 & 77.5 & 17.9 & 71 & 2.69 \\
\hline MK & 55 & M & 163 & 129.0 & 103.5 & 25.5 & 96 & 1.22 \\
\hline BS & 29 & $\mathrm{~F}$ & 162 & 129.3 & 110.6 & 18.7 & 118 & 1.59 \\
\hline MS & 23 & $\mathbf{M}$ & 191 & 161.4 & 130.4 & 31.0 & 99 & 2.50 \\
\hline RS & 22 & $\mathbf{M}$ & 185 & 140.0 & 112.2 & 27.8 & 84 & 1.32 \\
\hline PW & 28 & $\mathrm{~F}$ & 163 & 99.7 & 84.2 & 15.5 & 74 & 2.00 \\
\hline
\end{tabular}

* From Metropolitan Life Insurance Tables, 1959.

$\ddagger$ Intravenous glucose tolerance test performed before weight reduction. Values expressed as absolute per cent disappearance per minute (after glucose, $0.5 \mathrm{~g} / \mathrm{kg}$ ).

levels of the hormone. The current study was designed to quantify the in vivo metabolic effects of glucagon when given by constant infusion in more physiologic dosage in fasting man. In addition, levels of endogenous glucagon throughout periods of prolonged fasting have been determined.

\section{METHODS}

Subjects. 15 obese subjects were admitted to The Clinical Center of the Peter Bent Brigham Hospital (Table I) ; each had been carefully screened prior to fasting to assure that no endocrine abnormality was present. None had a history, signs, or symptoms of cardiac, renal, or hepatic disease or gout. The screening tests employed have been described (8). The patients were informed of the nature, purpose, and possible risks involved in fasting and in the infusion procedures, and each had volunteered to undergo prolonged fasting as a therapeutic measure.

The patients were not losing weight prior to admission, and for at least 3 days before fasting they received a 2500 calorie diet containing $300 \mathrm{~g}$ of carbohydrate, $100 \mathrm{~g}$ of protein, and $85 \mathrm{~g}$ of fat. Daily intake during fasting (35-43 days) consisted of a minimum of $2000 \mathrm{ml}$ of water, $17 \mathrm{mEq}$ of $\mathrm{NaCl}$, one multivitamin tablet (Theragran; E. R. Squibb \& Sons, New York), and, in most patients, $17 \mathrm{mEq}$ of $\mathrm{KCl}$. These medications contained no appreciable calories. No dietetic food or beverage or other intake was permitted.

Blood and urine collection and analyses. Blood was drawn between 8 and 9 a.m. from an antecubital vein without stasis with patients recumbent for at least $90 \mathrm{~min}$. It was immediately distributed into tubes for the analyses described. (a) Oxalate-fluoride tubes were used for triplicate blood glucose analyses by the Technicon AutoAnalyzer ferricyanide procedure (Technicon Corporation, Tarrytown,
N. Y.). (b) Tubes containing lithium-heparin were employed for analysis of free amino acids on plasma deproteinized with sulfosalicylic acid, as previously described (10), using the automated ion-exchange chromatographic technique on a Beckman 120C amino acid analyzer (Beckman Instruments Inc., Palo Alto, Calif.) modified to provide simultaneous recording from two columns. Glutamine and glutamate are not reliably quantified in plasma by this method and where reported were determined by specific enzymatic assay (11). Filtrates were immediately frozen and stored at $-20^{\circ} \mathrm{C}$ until analysis. (c) Clotted blood was collected for determination of serum immunoreactive insulin and immunoreactive growth hormone. (d) Plasma for assay of immunoreactive glucagon (12) was obtained from blood collected in tubes containing EDTA and Trasylol (FBA Pharmaceuticals Ltd., N. Y.). (e) Precooled tubes containing $30 \%$ $(w / v)$ perchloric acid received blood for instantaneous deproteinization for determination of $\beta$-hydroxybutyrate, acetoacetate, lactate, and pyruvate by modified enzymatic fluorimetric procedures and glycerol by an enzymatic spectrophotometric method. $(f)$ Free fatty acids were determined on heparinized plasma and were shown not to be artificially elevated by the levels of ketones present.

Urine was collected in plastic containers and stored at $4^{\circ} \mathrm{C}$ in $24-\mathrm{hr}$ collections, the total volumes of which were measured and aliquots taken for analysis of total nitrogen, urea nitrogen, ammonia, creatinine, uric acid, $\beta$-hydroxybutyrate, acetoacetate, and electrolytes. These were frozen at $-20^{\circ} \mathrm{C}$ until analysis. All analytical techniques for blood and urine have been described (13).

Statistical analyses were performed according to Snedecor (14).

Infusion procedures. Crystalline beef and pork glucagon (courtesy of Dr. Walter N. Shaw, Eli Lilly \& Co., Indianapolis, Ind.) was given, by constant infusion over $48 \mathrm{hr}$, 

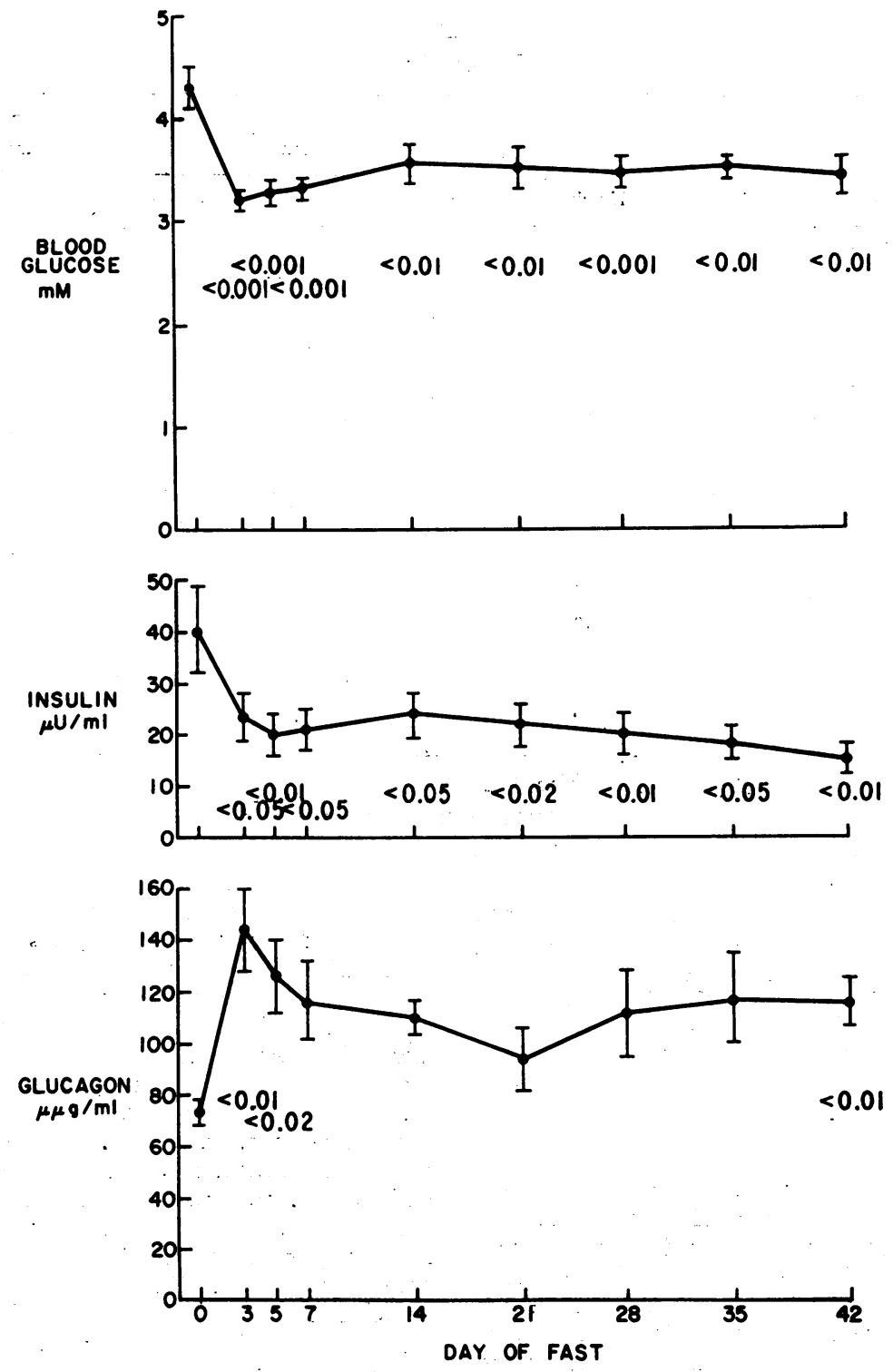

Figure 1 Concentration of blood glucose; serum insulin, and plasma glucagon in seven obese subjects at various intervals: throughout a prolonged fast. Values are mean $\pm_{S E M}$ and show the probability that concentrations during fasting do not differ from those on day zero (paired $t$ test).

on one or two occasions to each patient after at least 28 days of fasting. Infusion was maintained constant by an infusion pump (Harvard Apparatus Co., Millis, Mass.) into a slow drip of physiologic saline in a superficial forearm vein. Blood was sampled from the contralateral antecubital vein just prior to and at 8-hr intervals during the procedure (i.e., at 8 a.m., 4 p.m, and midnight on each of 2 days, and just prior to termination of the infusion). The infusate was prepared in physiologic saline containing 250 $\mathrm{mg} / 100 \mathrm{ml}$ of human serum albumin (E. R. Squibb \& Sons, New York), to prevent adherence of the glucagon to the glass and tubing. This was verified by immunoassay of glucagon in the infusate which contained $109 \pm 2 \%$ of the calculated amount. The infusate was similarly assayed for immunoreactive insulin and was found to contain $85 \mathrm{mU}$ of insulin per $\mathrm{mg}$ of glucagon, a physiologically insignificant amount at the rate infused.

Three dose levels of glucagon were used to deliver the following over a $24 \mathrm{hr}$ period: $10 \mathrm{mg}$ (four subjects), $1 \mathrm{mg}$ (five subjects), and $0.1 \mathrm{mg}$ (five subjects). In those receiving two infusions, 5-7 days were allowed between infusions to permit return to baseline conditions, and the lower dose was administered prior to the higher dose.

Since pronounced circadian changes in plasma amino acids and other metabolites are present in the fed state, which could themselves mitigate changes induced by infusion of 
TABLE II

Circadian Pattern of Circulating Substrates and Hormones on Day 28 of Prolonged Fasting (Seven Subjects)*

\begin{tabular}{lccc}
\hline & 8 a.m. & 4 p.m. & Midnight \\
\hline Blood glucose $(m M)$ & $3.42 \pm 0.14$ & $3.52 \pm 0.30$ & $3.27 \pm 0.19$ \\
$(m g / 100 m l)$ & $62 \pm 3$ & $63 \pm 5$ & $59 \pm 3$ \\
Serum insulin $(\mu U / m l)$ & $13 \pm 2$ & $17 \pm 4$ & $14 \pm 2$ \\
Plasma free fatty acids $(m E q /$ liter $)$ & $1.16 \pm 0.06$ & $1.32 \pm 0.15$ & $1.23 \pm 0.11$ \\
Blood $\beta$-hydroxybutyrate $(m M)$ & $6.19 \pm 0.36$ & $6.34 \pm 0.32$ & $6.26 \pm 0.34$ \\
Blood acetoacetate $(m M)$ & $1.14 \pm 0.08$ & $1.14 \pm 0.09$ & $1.25 \pm 0.08$ \\
Blood glycerol $(m M)$ & $0.157 \pm 0.030$ & $0.256 \pm 0.048$ & $0.209 \pm 0.059$
\end{tabular}

* Mean \pm sEM.

$\ddagger$ None of the values for 4 p.m. or midnight were significantly different from the 8 a.m. values by paired comparison $(P>0.05)$.

glucagon, samples were taken at 8 a.m., 4 p.m., and midnight of day 28 of fasting in seven patients, during which time no glucagon was administered. Similarly, a $24 \mathrm{hr}$ infusion of albumin in saline alone was administered to one patient (L. D.) to determine if the albumin affected the same parameters.

\section{RESULTS}

The mean morning values of blood glucose and plasma immunoreactive glucagon and serum insulin at day 0 (postabsorptive) and at intervals throughout a prolonged period of fasting in seven subjects are presented in Fig. 1. There was a significant rise in glucagon from the postabsorptive mean of $73 \mu \mu \mathrm{g} / \mathrm{ml}$ (SEM \pm 4.7$)$ to a maximum on day 3 of $144 \pm 15.7 \mu \mu \mathrm{g} / \mathrm{ml}(P<0.01)$. This rise was followed by a gradual return toward prefast levels, but the values remained significantly elevated at day 5,14 , and 42 . This early rise is identical with that previously reported using the same immunoassay (6) in nonobese subjects fasted 4 days. Also similar is the fall in insulin levels with fasting, a well-recognized phenomenon which is clearly associated with falling glucose concentrations. Thus the hormonal milieu of prolonged fasting is characterized by lowered insulin levels, elevated or normal immunoreactive glucagon levels, and low blood glucose.

Table II presents the results of circulating hormones and substrates measured three times during the 28th day of fasting without hormone infusion. No significant variation from 8 a.m. values was present by paired comparison of 4 p.m. and midnight values. Similarly, but not shown, no change occurred in any of these parameters in patient $\mathrm{L}$. D. during infusion of human serum albumin $(2.5 \mathrm{~g} / 24 \mathrm{hr})$ in saline without glucagon. The amino acid patterns of these patients are presented in Table III, and again no significant change in concentration of the individual amino acids was noted.

The responses of circulating substrates and hormones to glucagon infusion at two dose levels : $(10 \mathrm{mg} / 24 \mathrm{hr}$ and $1 \mathrm{mg} / 24 \mathrm{hr}$ ) are shown in Table IV and Fig. 2. Blood glucose rose with infusion of both doses of glucagon and was significant $(P<0.05$, paired $t$ test $)$ at most sampling intervals. The higher dose infusion pro-

TABLE III

Circadian Pattern of Individual Plasma Free Amino Acids on Day 28 of Prolonged Fasting (Five Subjects)*

\begin{tabular}{|c|c|c|c|}
\hline & 8 a.m. & 4 p.m. $\ddagger$ & Midnight \\
\hline & $\mu M$ & $\mu M$ & $\mu M$ \\
\hline Taurine & $66 \pm 7$ & $64 \pm 6$ & $70 \pm 6$ \\
\hline Threonine & $248 \pm 33$ & $223 \pm 28$ & $230 \pm 33$ \\
\hline Serine & $139 \pm 11$ & $127 \pm 10$ & $133 \pm 14$ \\
\hline Glutamine§ & $387 \pm 109$ & $448 \pm 87$ & $361 \pm 90$ \\
\hline Proline & $163 \pm 14$ & $162 \pm 15$ & $166 \pm 15$ \\
\hline Glutamic acid§ & $24 \pm 1$ & $31 \pm 3$ & $24 \pm 1$ \\
\hline Citrulline & $19 \pm 3$ & $20 \pm 3$ & $19 \pm 3$ \\
\hline Glycine & $372 \pm 14$ & $347 \pm 22$ & $356 \pm 26$ \\
\hline Alanine & $174 \pm 11$ & $175 \pm 9$ & $184 \pm 11$ \\
\hline \multicolumn{4}{|l|}{$\alpha$-Amino- $n-$} \\
\hline butyric acid & $49 \pm 6$ & $42 \pm 2$ & $44 \pm 2$ \\
\hline Valine & $211 \pm 21$ & $197 \pm 12$ & $205 \pm 12$ \\
\hline Half-cystine & $70 \pm 9$ & $79 \pm 7$ & $79 \pm 7$ \\
\hline Methionine & $31 \pm 3$ & $34 \pm 2$ & $32 \pm 3$ \\
\hline Issleucine & $91 \pm 7$ & $85 \pm 6$ & $88 \pm 7$ \\
\hline Leucine ... & $145 \pm 12$ & $132 \pm 8$ & $140 \pm 8$ \\
\hline Tyrosine & $59 \pm 3$ & $55 \pm 2$ & $55 \pm 2$ \\
\hline Phenylalanine & $48 \pm 4$ & $51 \pm 1$ & $47 \pm 2$ \\
\hline Ornithine & $55 \pm 7$ & $51 \pm 4$ & $56 \pm 5$ \\
\hline Lysine & $221 \pm 21$ & $204 \pm 16$ & $200 \pm 29$ \\
\hline Histidine & $68 \pm 10$ & $61 \pm 2$ & $63 \pm 7$ \\
\hline Arginine & $70 \pm 14$ & $59 \pm 6$ & $62 \pm 6$ \\
\hline
\end{tabular}

* Mean 土sEM.

$\ddagger$ None of the values for 4 p.m. or midnight were significantly different from the 8 a.m. values by paired comparison $(P \rightarrow 0.05)$.

\&lutamine and glutamic acid were determined separately by specific enzymatic methods." 
TABLE IV

Influence of Glucagon Infusion during Prolonged Fasting

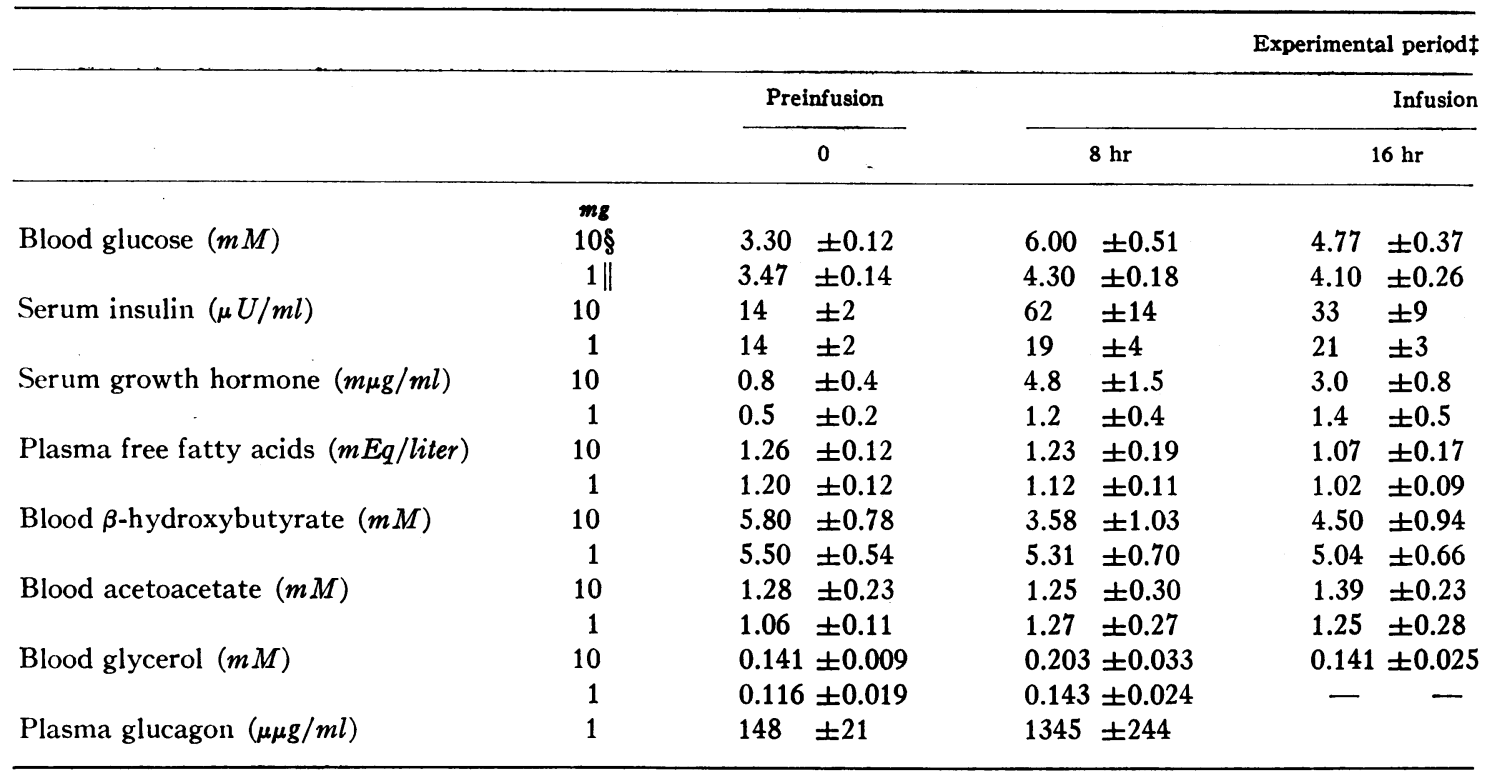

* Values are mean \pm SEM.

$\ddagger$ Hours from beginning of infusion. Zero time value is mean of 8 a.m. values on 3 days preceding infusion (except glucagon).

$\S 48 \mathrm{hr}$ infusion of $10 \mathrm{mg} / 24 \mathrm{hr}(n=4)$ of glucagon.

$\| 48$-hr infusion of $1 \mathrm{mg} / 24 \mathrm{hr}(n=5)$ of glucagon.

duced higher glucose and insulin levels, but there was much interindividual variation.

Glucagon levels in excess of $2000 \mu \mu \mathrm{g} / \mathrm{ml}$ were achieved and maintained throughout the infusions of $10 \mathrm{mg} / 24$ $\mathrm{hr}$. In the $1 \mathrm{mg} / 24 \mathrm{hr}$ infusions, the plasma concentrations were still above the peripheral venous levels of glucagon observed by stimulation of endogenous secretion (6), but within the range measured in portal venous plasma in animals (15) and in peripheral venous plasma in man in diabetic acidosis (12).

Serum growth hormone levels rose in both groups to significantly higher than preinfusion levels at $16 \mathrm{hr}$ $(P<0.05$, paired $t$ test $)$. Again the absolute values were higher with the $10 \mathrm{mg} / 24 \mathrm{hr}$ dose, but interpretation of these is complicated by the fact that this group comprised two females and two males, whereas the five subjects in the $1 \mathrm{mg} / 24 \mathrm{hr}$ dose group were all males (although zero time values were not significantly different).

Mean plasma free fatty acids underwent a slight but insignificant fall in the first $24 \mathrm{hr}$, followed by a secondary rise in the next $24 \mathrm{hr}$ which, though greater in the higher dose group, reached significantly greater than baseline values only in the $1 \mathrm{mg} / 24 \mathrm{hr}$ group at $32 \mathrm{hr}$ $(P<0.05$, paired $t$ test). A similar pattern was observel for blood $\beta$-hydroxybutyrate in the $10 \mathrm{mg} / 24 \mathrm{hr}$ studies, but a progressive decline occurred in the lower dose group, which was significant compared with the control value at $24 \mathrm{hr}(P<0.05$, paired $t$ test $)$. Blood acetoacetate and glycerol did not exhibit significant changes from preinfusion concentrations.

Urinary ketone acid excretion is shown in Table V. In both groups an increase in ketone excretion was observed, most marked in the $10 \mathrm{mg} / 24 \mathrm{hr}$ group. This increased excretion corresponded to the diminution in blood $\beta$-hydroxybutyrate on the 1 st day and the increase on the 2nd day of infusion in the higher dose group. But in the lower-dose group, the increase in urinary excretion was associated with a progressive decrease in blood levels.

The $24 \mathrm{hr}$ urinary total nitrogen excretion is shown in Fig. 3 as the sum of its components. The principal components, urea and ammonia nitrogen, are shown individually. The remainder, comprising creatinine, uric acid, and other undetermined nitrogenous compounds (including alpha-amino nitrogen) are shown together. None of the latter measured components changed significantly during infusion. The pattern and magnitude of the preinfusion nitrogen components are compatible with results previously published, in which ammonia excretion is equal to or greater than urea excretion, reflecting the important role of the kidney in both glu- 
on Circulating Substrate and Hormone Concentrations*

\begin{tabular}{|c|c|c|c|c|c|c|c|c|c|c|c|}
\hline \multicolumn{8}{|c|}{ Infusion } & \multicolumn{4}{|c|}{ Postinfusion } \\
\hline \multicolumn{2}{|r|}{$24 \mathrm{hr}$} & \multicolumn{2}{|r|}{$32 \mathrm{hr}$} & \multicolumn{2}{|c|}{$40 \mathrm{hr}$} & \multicolumn{2}{|r|}{$48 \mathrm{hr}$} & \multicolumn{2}{|c|}{$72 \mathrm{hr}$} & \multicolumn{2}{|r|}{$96 \mathrm{hr}$} \\
\hline 4.80 & \pm 0.24 & 5.49 & \pm 0.40 & 5.96 & \pm 0.83 & 6.48 & \pm 0.58 & 4.31 & \pm 0.19 & 3.85 & \pm 0.18 \\
\hline 4.38 & \pm 0.24 & 3.89 & \pm 0.22 & 4.17 & \pm 0.14 & 4.02 & \pm 0.21 & 3.54 & \pm 0.06 & 3.71 & \pm 0.21 \\
\hline 42 & \pm 13 & 37 & \pm 8 & 36 & \pm 7 & 52 & \pm 18 & 22 & \pm 2 & 19 & \pm 7 \\
\hline 18 & \pm 5 & 19 & \pm 4 & 13 & \pm 1 & 19 & \pm 3 & 14 & \pm 2 & 13 & \pm 1 \\
\hline 5.4 & \pm 2 & 3.4 & \pm 1.7 & 1.7 & \pm 0.5 & 1.4 & \pm 0.5 & 0.9 & \pm 0.2 & 0.9 & \pm 0.3 \\
\hline 0.6 & \pm 0.2 & 0.4 & \pm 0.2 & 0.5 & \pm 0.3 & 0.4 & \pm 0.2 & 0.4 & \pm 0.2 & 0.5 & \pm 0.2 \\
\hline 1.59 & \pm 0.64 & 1.77 & \pm 0.32 & 2.21 & \pm 0.65 & 1.85 & \pm 0.44 & 1.44 & \pm 0.24 & 1.49 & \pm 0.38 \\
\hline 1.21 & \pm 0.19 & 1.39 & \pm 0.15 & 1.34 & \pm 0.08 & 1.26 & \pm 0.18 & 1.11 & \pm 0.13 & 1.23 & \pm 0.27 \\
\hline 6.01 & \pm 0.46 & 6.70 & \pm 0.36 & 6.24 & \pm 0.59 & 4.63 & \pm 0.72 & 5.59 & \pm 0.90 & 5.48 & \pm 0.58 \\
\hline 4.92 & \pm 0.56 & 5.27 & \pm 0.60 & 4.11 & \pm 0.35 & 4.46 & \pm 0.75 & 5.65 & \pm 0.50 & 5.58 & \pm 1.26 \\
\hline 1.48 & \pm 0.23 & 1.64 & \pm 0.20 & 1.60 & \pm 0.20 & 1.42 & \pm 0.21 & 1.43 & \pm 0.25 & 1.38 & \pm 0.21 \\
\hline 1.26 & \pm 0.26 & 1.22 & \pm 0.26 & 0.85 & \pm 0.13 & 1.24 & \pm 0.23 & 1.38 & \pm 0.18 & 1.30 & \pm 0.35 \\
\hline- & - & 0.115 & \pm 0.010 & \multicolumn{2}{|c|}{$0.208 \pm 0.037$} & \multicolumn{2}{|c|}{$0.160 \pm 0.020$} & \multicolumn{2}{|c|}{$0.192 \pm 0.031$} & \multicolumn{2}{|c|}{$0.236 \pm 0.067$} \\
\hline \multirow{2}{*}{\multicolumn{2}{|c|}{$\begin{array}{l}0.142 \pm 0.032 \\
1176 \pm 190\end{array}$}} & \multirow{2}{*}{\multicolumn{2}{|c|}{$0.184 \pm 0.022$}} & - & - & \multicolumn{2}{|c|}{$0.176 \pm 0.028$} & 0.134 & \pm 0.017 & \multirow{2}{*}{\multicolumn{2}{|c|}{$0.125 \pm 0.035$}} \\
\hline & & & & & & 752 & \pm 166 & & & & \\
\hline
\end{tabular}

coneogenesis and acid-base homeostasis in this state (8). Day 1 of the infusion was, in general, several days later in the fast for the group receiving $10 \mathrm{mg}$ of glucagon per $24 \mathrm{hr}$, probably in part accounting for the somewhat lower urea nitrogen excretion for this group in the perinfusion period.

The effect noted in both groups was an increase in urea nitrogen excretion beginning on the 1st day and becoming significant on the 2 nd day of infusion. Levels returned to preinfusion values promptly in the lower dose group, but they remained elevated for several days after the termination of the $10 \mathrm{mg} / 24 \mathrm{hr}$ infusions. No change in ammonia nitrogen excretion occurred. This is consistent with the failure of glucagon infusion to have altered the blood acid-base equilibrium typical of prolonged fasting (compensated metabolic acidosis).

Concurrent with the increase in urea nitrogen excretion, the plasma concentrations of individual free amino acids showed striking changes (Table VI). All amino acids measured during the $10 \mathrm{mg} / 24 \mathrm{hr}$ infusions diminished significantly, and only taurine and phenylalanine failed to diminish during the $1 \mathrm{mg} / 24 \mathrm{hr}$ infusions. In every other instance, the response to the lower dose infusions was similar to but smaller in magnitude than the response to the higher dose. Apart from taurine and phenvlalanine in the $1 \mathrm{mg} / 24 \mathrm{hr}$ infusions, three general patterns of response were observed. Two of these are demonstrated by representative amino acids in Fig. 4. The first group is represented by glycine and is characterized by either a progressive decline in plasma concentration or a decline to a plateau. This group includes serine, proline, citrulline, alanine, $\alpha$-aminobutyric acid, half cystine, ornithine, and arginine. The second group, represented by leucine, showed a transient decrease followed by a return to levels not significantly different from preinfusion by $24 \mathrm{hr}$. Included were valine, leucine, and isoleucine ( $1 \mathrm{mg} / 24 \mathrm{hr}$ only). Methionine similarly decreased transiently but remained significantly lower until after the 24-hr interval. A third response, that of lysine and histidine (in the $10 \mathrm{mg} / 24 \mathrm{hr}$ studies), was a decrease, a recovery toward preinfusion at $24 \mathrm{hr}$, then a subsequent decrease.

The zero time values in the two groups were comparable and in both instances showed the pattern previously published for prolonged-fasted subjects (10).

The responses of the five subjects receiving $0.1 \mathrm{mg} / 24$ hr are shown in Fig. 5. No change in blood glucose or insulin occurred during the significant elevation of immunoreactive glucagon from the preinfusion mean of $102 \pm 3$ to a mean of $143-180 \mu \mu \mathrm{g} / \mathrm{ml}$. Similarly, plasmafree fatty acids and blood ketones did not change. Growth hormone was not determined. Urinary $\beta$-hydroxybutyrate 

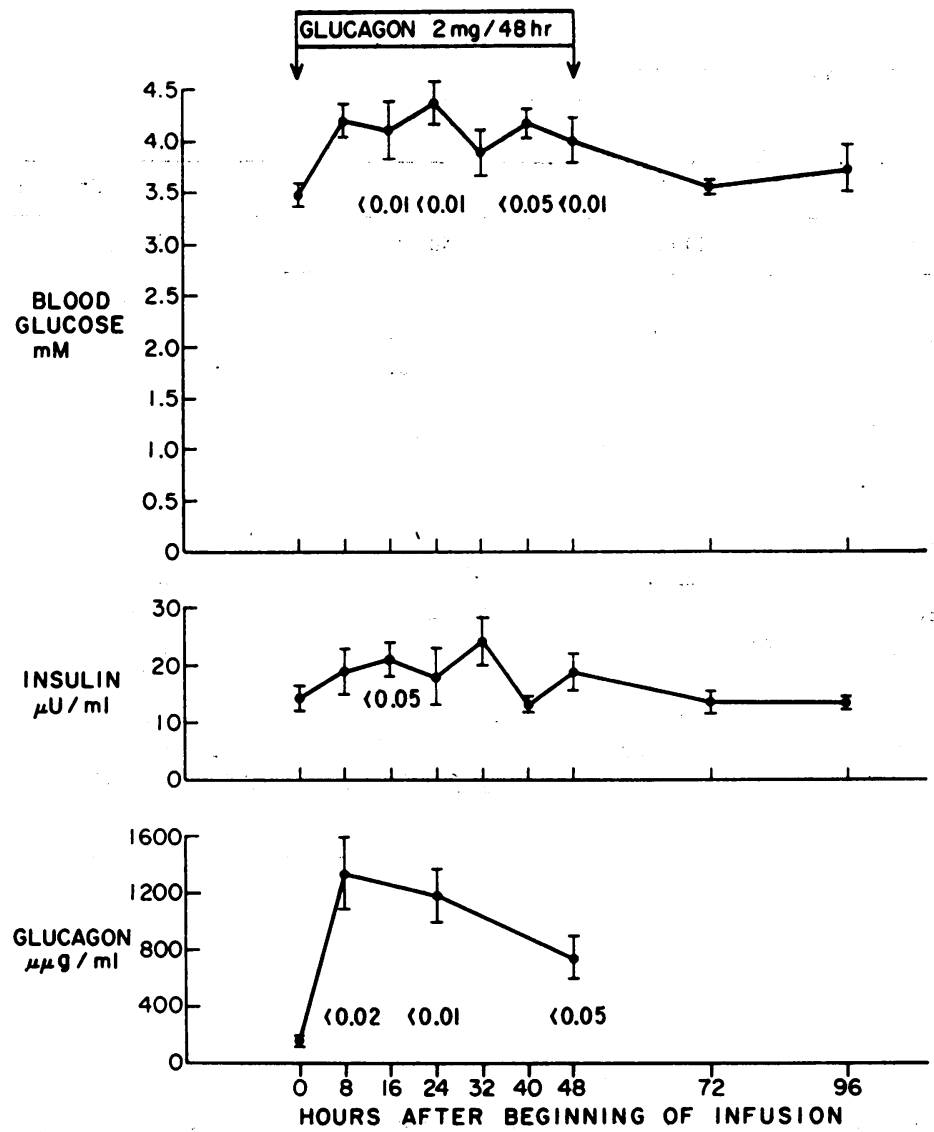

Figure 2 Influence of $48 \mathrm{hr}$ glucagon infusion $(1 \mathrm{mg} / 24 \mathrm{hr})$ on blood glucose, serum insulin, and plasma glucagon. Values are mean ISEM for five prolonged-fasted subjects and show the probability that concentrations during infusion do not differ from zero time (paired $t$ test). Zero time value of glucose and insulin is the mean of the 3 days preceding infusion.

increased significantly during the first $24 \mathrm{hr}(P<0.01)$ but returned to baseline thereafter. Acetoacetate excretion did not change significantly. Urine nitrogen responses are shown in Fig. 6, and these contrast with the higher dose groups (Fig. 3), in that a significant fall in urea nitrogen excretion occurred. Whether this fall is greater than would have occurred without intervention cannot be determined.

Individual plasma amino acids whose levels fell significantly $(P<0.05$, paired $t$ test) during these infusions are shown in Fig. 7. Particularly noteworthy are the decreases in threonine, serine, and glycine, which are elevated with prolonged fasting and which show a postinfusion rebound. There was no change in the con-centration of the remaining measured amino acids.:

\section{DISCUSSION}

Circadian rhythm of substrate and insulin concentrations. The studies performed on day 28 confirm that the near steady-state metabolic adaptation of prolonged fasting obtains without significant variation in the parameters examined in relation to time of day. Thus any changes demonstrated during glucagon infusion may be attributed solely to the effects of the hormone.

Though circadian changes in blood glucose and serum insulin unrelated to meal taking in the fed state have been suggested $(16,17)$, such changes did not occur during prolonged fasting. Similarly, the measured parameters reflecting fat mobilization (free fatty acid and glycerol) and hepatic oxidation of fatty acid (the levels of ketone acids) do not show variations at the times of the day studied. These observations suggest that the glucoregulatory and fat-mobilizing mechanisms which result in the fasting adaptation are not regulated by hormones whose secretion may show circadian change, or change related to intermittent activity (though the subjects were recumbent for 90 min prior to blood sampling). 
TABLE V

Urinary Ketone Acid Excretion during and following Glucagon Infusion in Prolonged Fasting*

\begin{tabular}{|c|c|c|c|c|c|c|c|c|c|}
\hline & & \multirow{2}{*}{$\begin{array}{l}\text { Preinfusion } \\
\text { period }\end{array}$} & \multicolumn{2}{|c|}{ Infusion period } & \multicolumn{5}{|c|}{ Postinfusion period } \\
\hline & & & Day 1 & Day 2 & Day 1 & Day 2 & Day 3 & Day 4 & Day 5 \\
\hline & $m g$ & & & & & & & & \\
\hline \multirow[t]{2}{*}{$\beta$-hydroxybutyrate } & $10 \S$ & $107 \pm 17$ & $133 \pm 29$ & $254 \pm 46 \|$ & $108 \pm 23$ & $80 \pm 25 \|$ & $74 \pm 6$ & $83 \pm 34$ & - \\
\hline & $1 \pi$ & $103 \pm 15$ & $127 \pm 13^{* *}$ & $150 \pm 20 \ddagger \ddagger$ & $106 \pm 18$ & $101 \pm 12$ & $86 \pm 6$ & $99 \pm 4$ & $79 \pm 6$ \\
\hline \multirow[t]{2}{*}{ Acetoacetate } & 10 & $8 \pm 1$ & $10 \pm 2$ & $23 \pm 5$ & $13 \pm 2$ & $10 \pm 1$ & $8 \pm 2$ & $9 \pm 2$ & - \\
\hline & 1 & $10 \pm 1$ & $11 \pm 1$ & $14 \pm 2$ & $10 \pm 1$ & $9 \pm 1$ & $8 \pm 1$ & $10 \pm 2$ & $8 \pm 1$ \\
\hline
\end{tabular}

* Mean \pm SEM (mM/24 hr).

¥ Mean of 5 days preceding infusion.

$\S 48 \mathrm{hr}$ infusion of $10 \mathrm{mg} / 24 \mathrm{hr}(n=4)$.

$\| P<0.05$, paired $t$ test vs. preinfusion meall.

I $48 \mathrm{hr}$ infusion of $1 \mathrm{mg} / 24 \mathrm{hr}(n=5)$.

** $P<0.02$, paired $t$ test vs. preinfusion mean.

$\sharp P<0.01$, paired $t$ test vs. preinfusion mean.

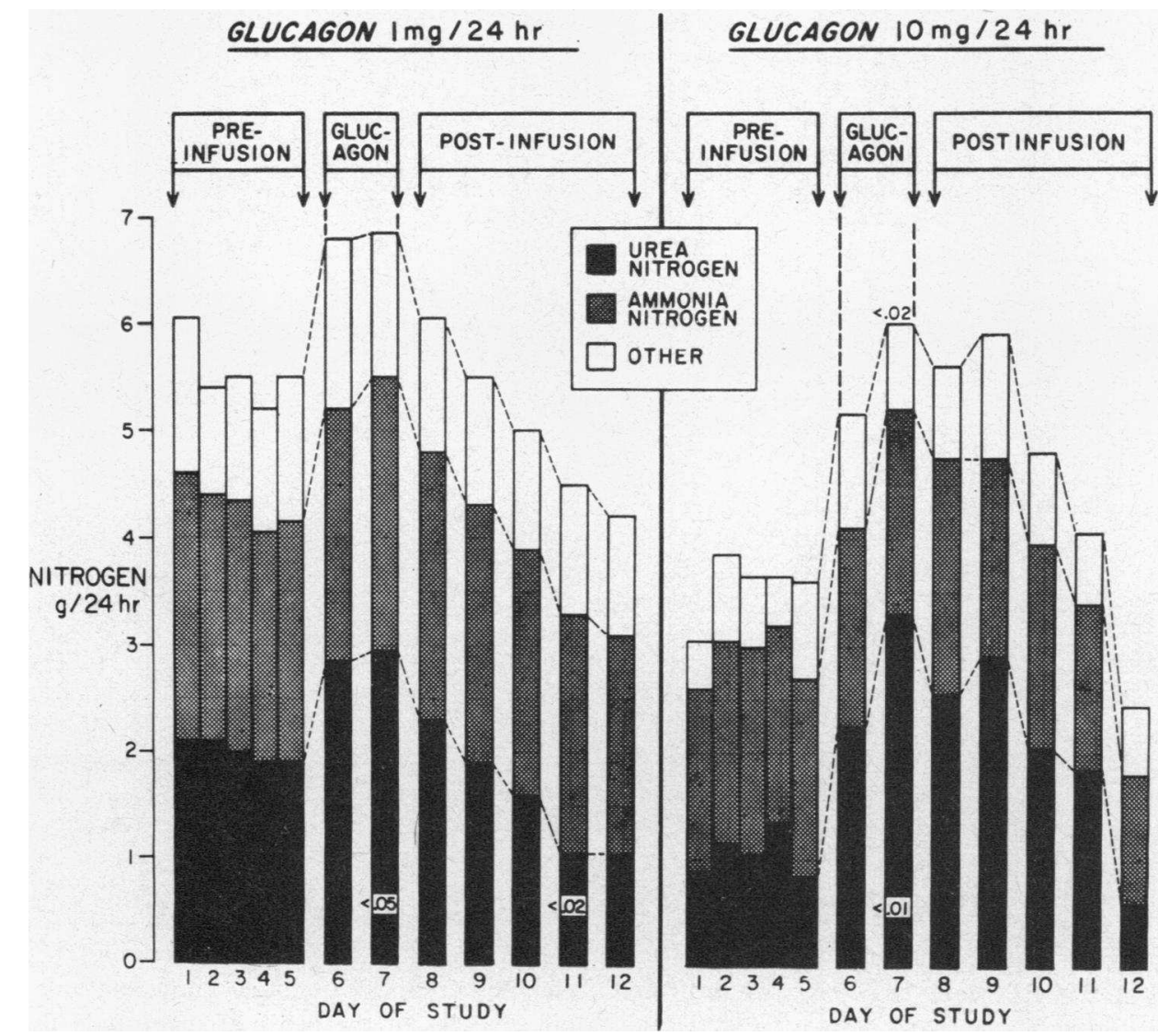

FIGURE 3 Influence of $48 \mathrm{hr}$ glucagon infusion ( $1 \mathrm{mg}$ and $10 \mathrm{mg} / 24 \mathrm{hr}$ ) on urine nitrogen excretion during prolonged fasting. Total height of bar represents total nitrogen, the urea and ammonia components of which are shown separately. Each bar represents the mean value, for five subjects in the $1 \mathrm{mg} / 24 \mathrm{hr}$ group and four subjects in the $10 \mathrm{mg} / 24 \mathrm{hr}$ group. Values on day 7 of both groups and day 11 of the $1 \mathrm{mg} / 24 \mathrm{hr}$ group show probability that the component shown does not differ from the mean of the preinfusion values (paired $t$ test). 
TABLE VI

Influence of 48-Hour Glucagon Infusions upon Individual Plasma Free Amino Acids in Prolonged Fasting

\begin{tabular}{|c|c|c|c|c|c|c|c|c|}
\hline & & \multirow[b]{2}{*}{ Zero time* } & \multicolumn{6}{|c|}{ Mean per cent decrease from zero time value } \\
\hline & & & $8 \mathrm{hr}$ & $P \ddagger$ & $24 \mathrm{hr}$ & $P$ & $48 \mathrm{hr}$ & $P$ \\
\hline & $m g$ & $\mu M$ & & & & & & \\
\hline \multirow[t]{2}{*}{ Taurine } & $10 \S$ & $68 \pm 3$ & 32 & $<0.01$ & 30 & $<0.02$ & 19 & NS \\
\hline & $1 \|$ & $57 \pm 4$ & 0 & NS & 12 & NS & -12 & NS \\
\hline \multirow[t]{2}{*}{ Threonine } & 10 & $228 \pm 14$ & 67 & $<0.001$ & 84 & $<0.01$ & 84 & $<0.01$ \\
\hline & 1 & $187 \pm 24$ & 29 & $<0.02$ & 49 & $<0.01$ & 56 & $<0.01$ \\
\hline \multirow[t]{2}{*}{ Serine } & 10 & $117 \pm 7$ & 61 & $<0.001$ & 67 & $<0.01$ & 56 & $<0.01$ \\
\hline & 1 & $133 \pm 9$ & 28 & $<0.01$ & 29 & $<0.02$ & 31 & $<0.01$ \\
\hline \multirow[t]{2}{*}{ Proline } & 10 & $145 \pm 21$ & 58 & $<0.01$ & 76 & $<0.01$ & 81 & $<0.01$ \\
\hline & 1 & $151 \pm 13$ & 21 & $<0.01$ & 30 & $<0.05$ & 30 & $<0.01$ \\
\hline \multirow[t]{2}{*}{ Citrulline } & 10 & $15 \pm 5$ & 63 & NS & 70 & NS & 81 & $<0.05$ \\
\hline & 1 & $17 \pm 2$ & 29 & $<0.05$ & 38 & NS & 37 & $<0.01$ \\
\hline \multirow[t]{2}{*}{ Glycine } & 10 & $341 \pm 54$ & 61 & $<0.01$ & 67 & $<0.01$ & 66 & $<0.01$ \\
\hline & 1 & $305 \pm 25$ & 23 & $<0.05$ & 31 & $<0.05$ & 33 & $<0.01$ \\
\hline \multirow[t]{2}{*}{ Alanine } & 10 & $144 \pm 15$ & 46 & $<0.01$ & 49 & $<0.05$ & 38 & $<0.05$ \\
\hline & 1 & $143 \pm 14$ & 21 & NS & 25 & NS & 24 & $<0.05$ \\
\hline \multirow{2}{*}{$\begin{array}{l}\alpha \text {-Amino- } n- \\
\text { butyric acid }\end{array}$} & 10 & $32 \pm 5$ & 61 & $<0.01$ & 59 & $<0.05$ & 74 & $<0.02$ \\
\hline & 1 & $35 \pm 1$ & 20 & $<0.02$ & 25 & $<0.05$ & 25 & $<0.01$ \\
\hline \multirow[t]{2}{*}{ Valine } & 10 & $157 \pm 14$ & 31 & $<0.001$ & 18 & NS & 22 & NS \\
\hline & 1 & $177 \pm 14$ & 17 & $<0.05$ & 11 & NS & 7 & NS \\
\hline \multirow[t]{2}{*}{ Half cystine } & 10 & $79 \pm 11$ & 37 & NS & 40 & $<0.05$ & 44 & NS \\
\hline & 1 & $67 \pm 6$ & 13 & NS & 25 & $<0.02$ & 27 & $<0.05$ \\
\hline \multirow[t]{2}{*}{ Methionine } & 10 & $24 \pm 5$ & 70 & $<0.02$ & 53 & $<0.01$ & 21 & NS \\
\hline & 1 & $29 \pm 1$ & 32 & $<0.01$ & 31 & $<0.02$ & 18 & NS \\
\hline \multirow[t]{2}{*}{ Isoleucine } & 10 & $76 \pm 7$ & 55 & $<0.01$ & 36 & $<0.05$ & 42 & $<0.05$ \\
\hline & 1 & $78 \pm 7$ & 22 & $<0.05$ & 9 & NS & 3 & NS \\
\hline \multirow[t]{2}{*}{ Leucine } & 10 & $110 \pm 11$ & 59 & $<0.001$ & 27 & NS & 32 & NS \\
\hline & 1 & $119 \pm 11$ & 24 & $<0.05$ & 9 & NS & 5 & NS \\
\hline \multirow[t]{2}{*}{ Tyrosine } & 10 & $49 \pm 4$ & 60 & $<0.02$ & 60 & $<0.01$ & 46 & $<0.01$ \\
\hline & 1 & $47 \pm 3$ & 22 & $<0.05$ & 19 & NS & 12 & NS \\
\hline \multirow[t]{2}{*}{ Phenylalanine } & 10 & $46 \pm 2$ & 46 & $<0.01$ & 18 & NS & 10 & NS \\
\hline & 1 & $43 \pm 4$ & 15 & NS & -2 & NS & -2 & $\mathrm{NS}$ \\
\hline \multirow[t]{2}{*}{ Ornithine } & 10 & $43 \pm 3$ & 62 & $<0.01$ & 67 & $<0.01$ & 74 & $<0.05$ \\
\hline & 1 & $47 \pm 6$ & 23 & NS & 47 & NS & 49 & $<0.05$ \\
\hline \multirow[t]{2}{*}{ Lysine } & 10 & $137 \pm 4$ & 59 & $<0.01$ & 32 & NS & 52 & $<0.01$ \\
\hline & 1 & $186 \pm 6$ & 30 & $<0.05$ & 40 & $<0.02$ & 36 & $<0.01$ \\
\hline \multirow[t]{2}{*}{ Histidine } & 10 & $57 \pm 2$ & 53 & $<0.05$ & 18 & NS & 26 & $<0.05$ \\
\hline & 1 & $60 \pm 1$ & 20 & $<0.001$ & 20 & $<0.05$ & 10 & NS \\
\hline \multirow[t]{2}{*}{ Arginine } & 10 & $66 \pm 7$ & 58 & NS & 63 & $<0.05$ & 62 & NS \\
\hline & 1 & $60 \pm 1$ & 33 & $<0.05$ & 43 & $<0.05$ & 43 & $<0.01$ \\
\hline
\end{tabular}

* Zero time value is value immediately prior to commencement of infusion. Mean \pm SEM.

$\ddagger$ Probability that per cent decrease is not different from zero (paired $t$ test).

$\S$ Infusion of $10 \mathrm{mg} / 24 \mathrm{hr}(n=4)$.

\|I Infusion of $1 \mathrm{mg} / 24 \mathrm{hr}(n=5)$.

A well-defined circadian rhythm of plasma amino acid concentrations in the fed state has been demonstrated (18), in which the nadir in levels of most amino acids occurs in the early morning and the peak at about 10 p.m. The obese patients studied herein in the fed state conformed to this pattern (unpublished data). However, after 4 wk of fasting there was no change in concentrations at the times samples were drawn ( 8 a.m., 4 p.m., and midnight). This finding does not preclude smaller changes occurring at other time intervals but does rule out changes of the order of magnitude that are seen in fed subjects. These observations support the contention ${ }^{1}$

${ }^{1}$ Hussein, M. A., V. R. Young, E. Murrary, and N. S. Scrimshaw. Diurnal fluctuations of plasma amino acids in adult men. Effect of dietary tryptophan intake and distribution of meals. Submitted for publication. 


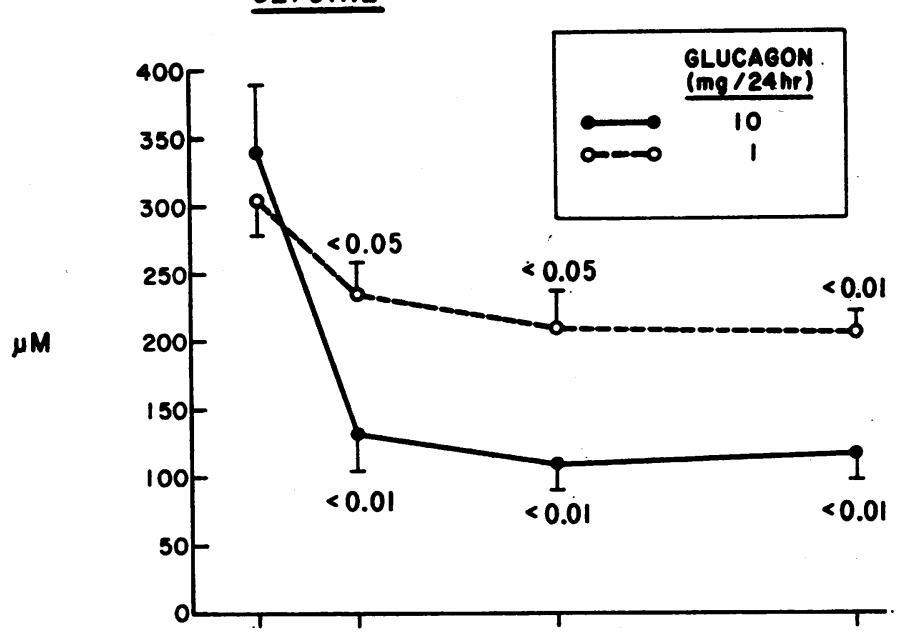

LEUCINE

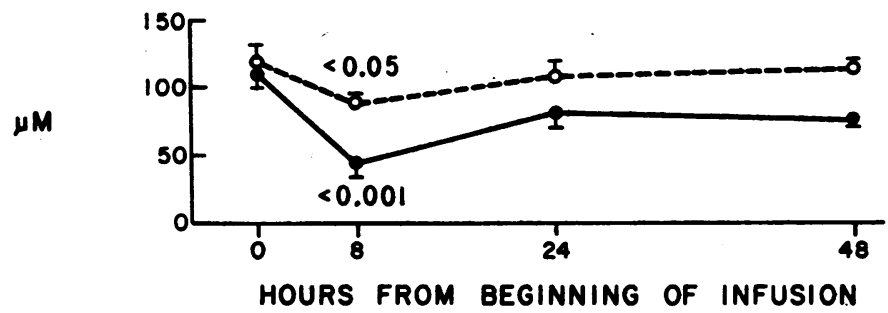

FIgURE 4 Influence of $48 \mathrm{hr}$ glucagon infusion during prolonged fasting on plasma glycine and leucine concentrations. Each represents the pattern of response of a group of amino acids (see text). Values for each dose level ( $1 \mathrm{mg} / 24 \mathrm{hr}$, five subjects; $10 \mathrm{mg} / 24 \mathrm{hr}$, four subjects) show probability that concentration does not differ from that at zero time (paired $t$ test).

(19) that the previously observed circadian amino acid rhythms are at least partly, if not entirely, patterned by meal taking and its induced hormonal responses.

Immunoreactive glucagon levels in prolonged fasting. The present findings confirm and amplify those of Aguilar-Parada, Eisentraut and Unger, who have recently demonstrated a $50 \%$ rise in glucagon levels in 3- and 4-day fasts in normal weight volunteers (6). The peak rise of $100 \%$ on day 3 of the present study thus corresponds closely to their observations. A similar early elevation of glucagon had been demonstrated previously $(3,20)$, but its interpretation was questioned because of the lack of antisera specific for pancreatic glucagon. The assay procedure used in the present study has been modified to exclude nonpancreatic glucagon-like immunoreactivity (12).

This early rise in plasma glucagon corresponds to a transient period of accelerated hepatic gluconeogenesis, as evidenced by urinary urea nitrogen and by enhanced splanchnic amino acid extraction. Indeed, an increase in the fractional splanchnic extraction of alanine, the principal gluconeogenic amino acid, from $43 \%$ postabsorptively to $71 \%$ on day 3 has been reported recently from this laboratory (10). Fractional alanine extraction returned to $53 \%$ at 5-6 wk of fasting, a pattern which correlates with the fall in glucagon toward postabsorptive levels beyond day 3 . Thus, a synergism of the decrease in circulating insulin and increase in glucagon may be viewed as the cause of stimulated hepatic gluconeogenic mechanisms early in fasting. Although the absolute level of glucagon later falls, the low insulin levels result in an increased ratio of glucagon to insulin, which persists and may be responsible for determining the proportion of amino acid extracted by the liver in prolonged fasting. The work of Mackrell and Sokal (21) in the isolated perfused rat liver has confirmed the importance of the relative concentrations of these hormones in regulating hepatic metabolism. Furthermore, Lewis, Exton, Ho, and Park (22) have recently demonstrated the minimum concentration of glucagon which stimulates gluconeogenesis 
from lactate in vitro to be approximataely $10^{-11}$ moles/liter $(35 \mu \mu \mathrm{g} / \mathrm{ml})$. Thus the increment in peripheral venous glucagon observed in fasting must reflect an increment in the portal venous concentration well within the range expected to be regulatory.

An additional effect of the early peak of glucagon may be to produce that amount of hepatic glycogenolysis which contributes in a quantitatively minor fashion to the glucose made available early in fasting in man (5). Similarly, a synergism with declining insulin levels on lipolysis may be another consequence of both the early absolute rise and sustained relative hyperglucagonemia.

The progressive diminution of gluconeogenesis from protein (8) cannot be ascribed to the above hepatic effects of glucagon. The liver remains able to convert amino acids to glucose, as demonstrated by the prompt and quantitative incorporation of alanine carbon into blood glucose upon infusion of $\mathrm{C}^{14}$ alanine (23). The control of the mobilization of protein for gluconeogenesis has been shown to reside at the muscle (the body's principal protein store), which determines the amount of amino acid substrate made available to liver. The amount of amino acid released during prolonged fasting is markedly curtailed (24). Whether glucagon may directly influence this muscle efflux is currently being studied.

That the initial glucagon rise might be related to the decrease in blood glucose has been suggested by several investigators who have proposed glucagon to be the primary hormone of chronic "glucose need" as well as of acute hypoglycemia. This may be an important regulator of glucagon secretion in other situations, but it cannot explain the secondary decline in glucagon levels, which occurs during a period of constant, though decreased, blood glucose concentration.

The control of the biphasic pattern of glucagon levels is thus unexplained. A relation exists, however, between the pattern of plasma branched-chain amino acid levels and glucagon, since a transient elevation in the
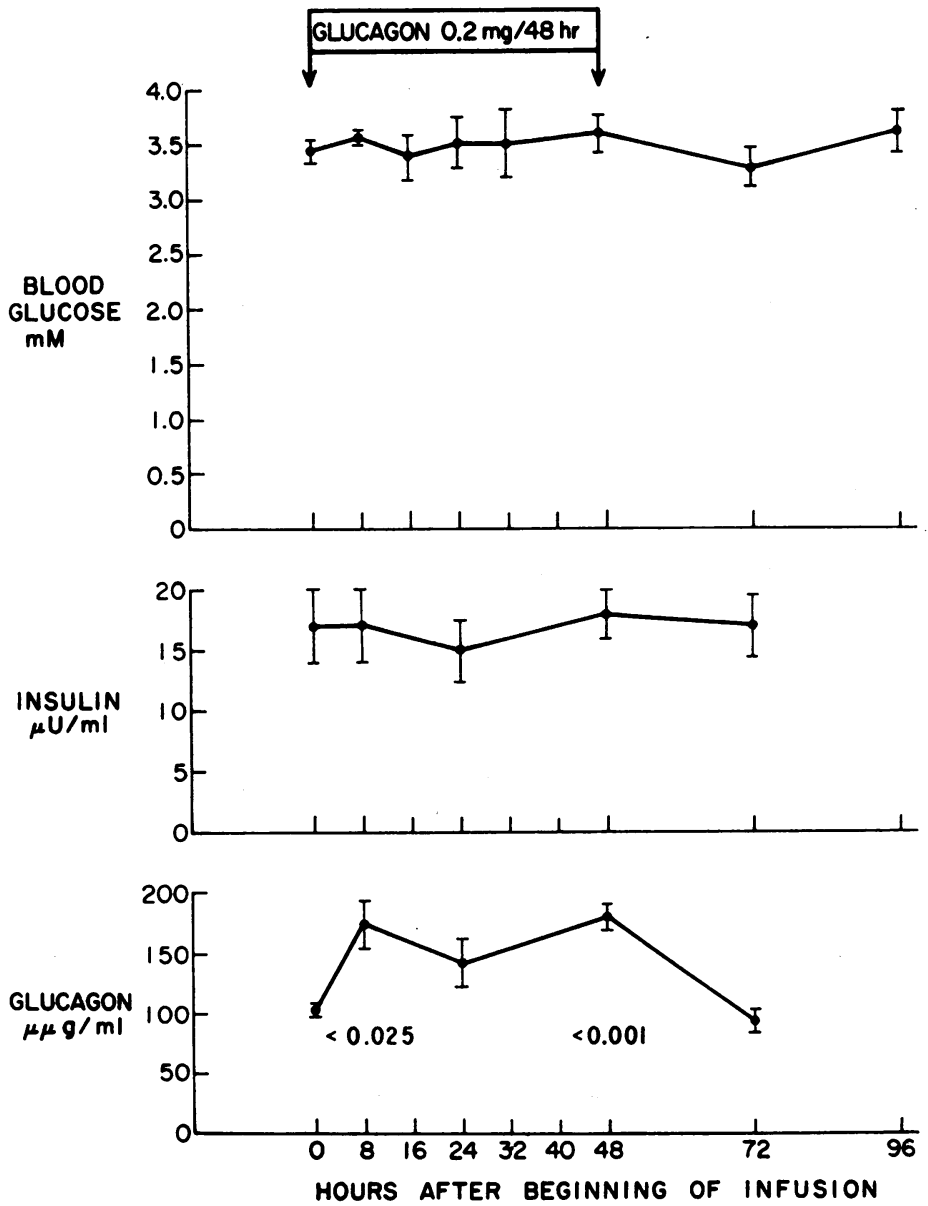

FigURE 5 Influence of $48 \mathrm{hr}$ glucagon infusion $(0.1 \mathrm{mg} / 24 \mathrm{hr})$ on blood glucose, serum insulin, and plasma glucagon in five prolongedfasted subjects. Data are presented as in Fig. 2. 


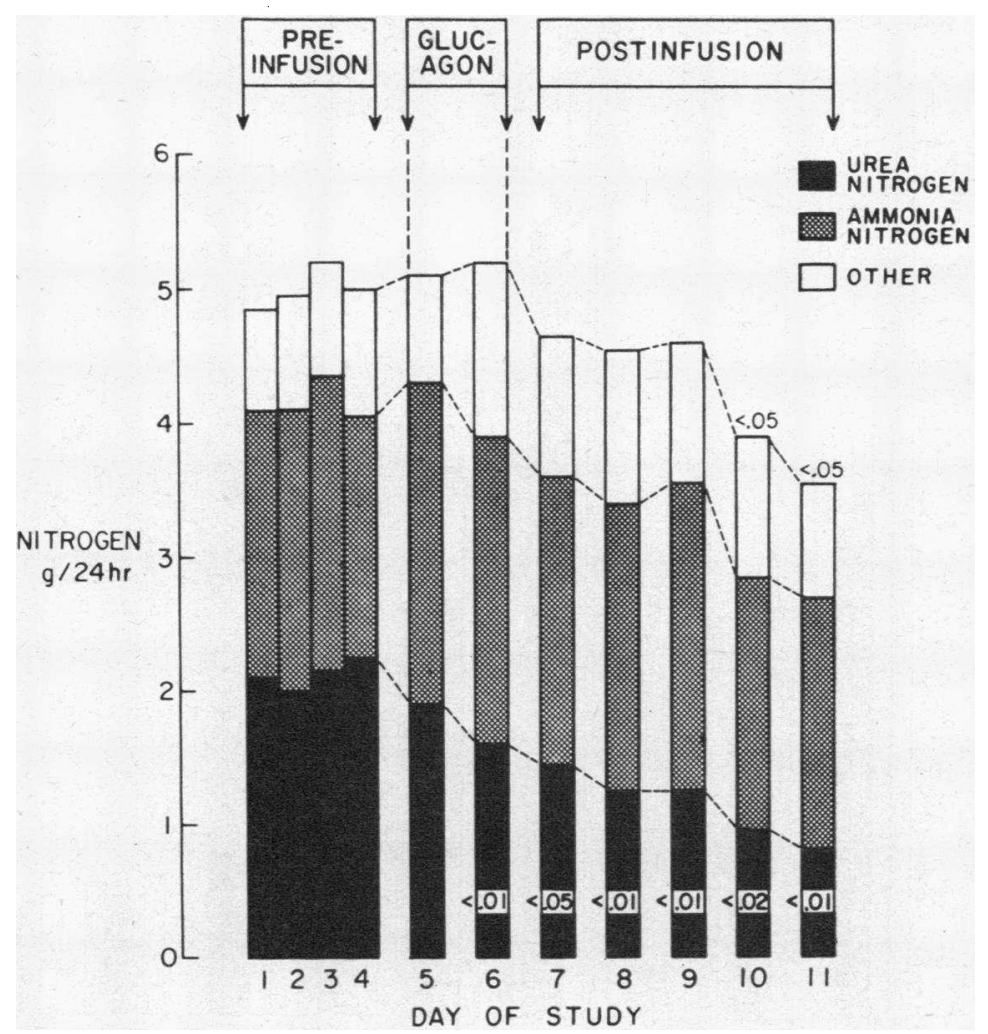

FIGURE 6 Influence of $48 \mathrm{hr}$ glucagon infusion $(0.1 \mathrm{mg} / 24 \mathrm{hr})$ on urine nitrogen excretion in five prolonged-fasted subjects. Data are presented as in Fig. 3.

former also occurs early in fasting (10). It is now well recognized that many amino acids are potent stimulators of glucagon as well as of insulin secretion (15). Felig, Marliss, and Cahill (25) recently proposed that endogenous levels of amino acids, particularly the branchedchain amino acids (valine, leucine, and isoleucine), may exert a tonic influence on beta cell secretory activity, secondary in sensitivity to the glucose levels. Thus, the rise in these amino acids seen early in fasting has been interpreted to be the result of declining blood glucose and insulin levels and a diminution in the known effect of insulin of inhibiting muscle release of these amino acids (26). It is possible that the early hyperglucagonemia may be a reflection of the increased levels of valine or isoleucine, and the secondary decline related to the decrease in the same amino acids. The possibility of enhanced glucagon responsiveness to endogenous levels of amino acids is also raised by the data of AguilarParada and colleagues in which glucagon increments in response to arginine infusion were greater in subjects fasted 3 days than in the same subjects in the postabsorptive state (6).

Glucagon infusions in prolonged fasting. The infusions of $10 \mathrm{mg} / 24 \mathrm{hr}$ were clearly pharmacologic in that the levels achieved were considerably greater than those observed in any physiologic setting. These infusions regularly induced moderate nausea and, on occasion, vomiting requiring treatment. Such an effect was not observed in the $1 \mathrm{mg} / 24 \mathrm{hr}$ infusions, which still produced high peripheral levels of glucagon. Nevertheless, the principal differences in the effects of the two doses upon circulating substrates and hormones are largely quantitative, since the same parameters were altered proportionally in both instances.

The mechanism of blood glucose elevation was probably largely due to increased gluconeogenesis (in addition to glycogenolysis) from amino acid precursors, as shown by the increase in urine urea nitrogen excretion. Similar results in fed subjects have been reported (27). This effect was primarily hepatic in locus, despite the role of the kidney in producing $50 \%$ of the body's total glucose requirement in prolonged fasting (8), because no effect on urinary ammonia excretion was seen. Renal gluconeogenesis and ammoniagenesis have been shown to be closely correlated in states of acidosis such as in fasting (28). The increase in hepatic gluconeogenesis occurred, despite substantial increase in serum insulin levels to a peak of $62 \mu \mathrm{U} / \mathrm{ml}( \pm 14)$ in the 10 


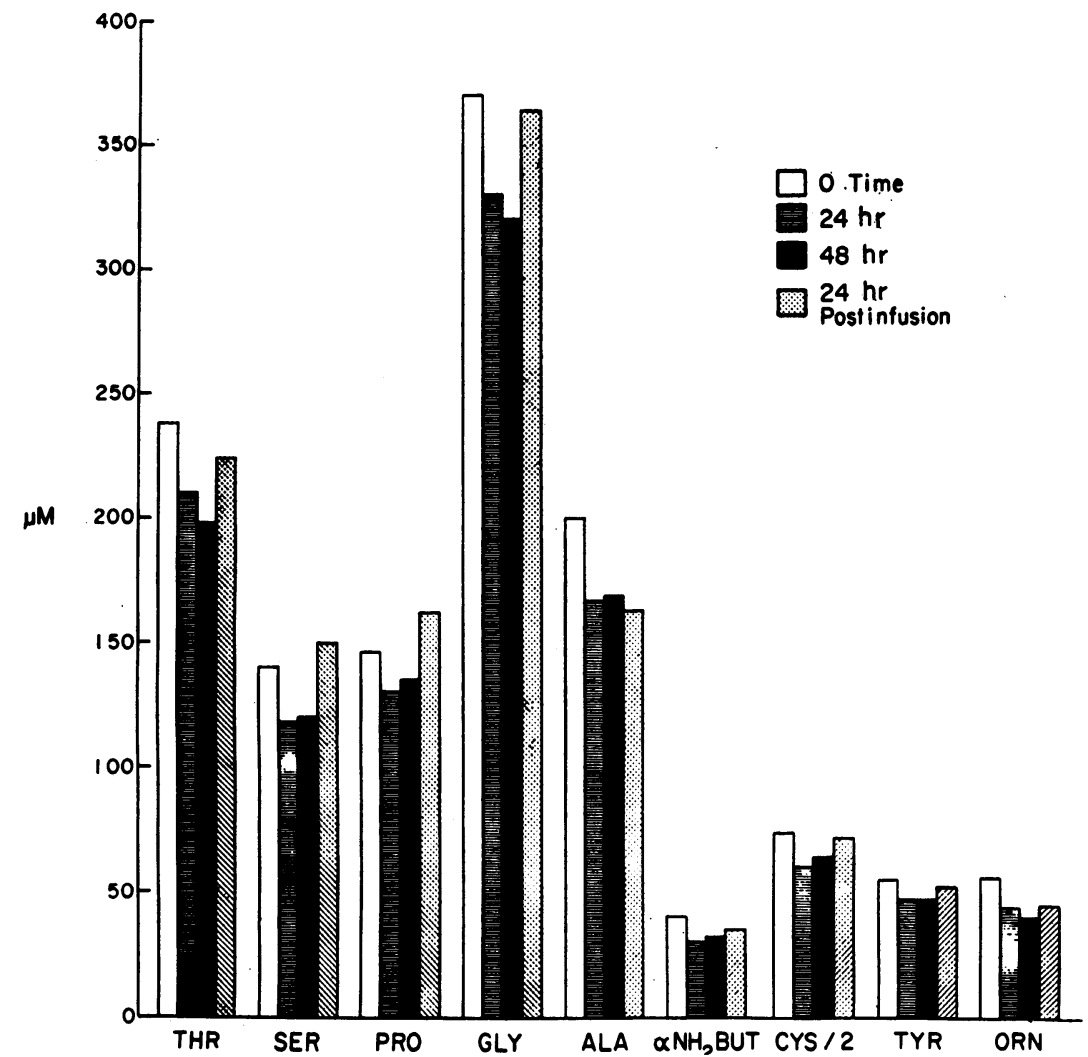

FIGURE 7 Individual plasma amino acids showing significant $(P<0.05$, paired $t$ test) decline in concentration during $48 \mathrm{hr}$ glucagon infusion $(0.1 \mathrm{mg} / 24 \mathrm{hr})$ in prolonged-fasted subjects. A return to levels not different from zero time occurred at $24 \mathrm{hr}$ postinfusion for all amino acids shown except alanine and ornithine.

$\mathrm{mg} / 24 \mathrm{hr}$ infusions, a value greater than the mean postabsorptive insulin concentration in this group (40 $\pm 8 \mu \mathrm{U} / \mathrm{ml}$ ). Whether this increment in insulin was due to the elevated blood glucose cencentration cannot be ascertained from the present study. It must be conceded, however, that the sensitivity of the beta cell to glucagon stimulation in this state must be very low, since extremely high concentrations of glucagon were present.

The biochemical mechanism whereby glucagon exerted its stimulatory effect on hepatic gluconeogenesis is not apparent. No clear evidence is provided of an increase in ketogenesis after glucagon, because of the altered blood levels in association with increased excretion, probably a direct effect of glucagon on renal ketone metabolism or excretion. Thus, an effect independent of acceleration of fatty acid oxidation remains a possibility.

The effect of glucagon on increasing lipolysis in vitro (29) and in vivo in other species (30) was not evident in these studies, in that plasma-free fatty acid and blood glycerol concentrations did not rise significantly.

\section{Marliss, Aoki, Unger, Soeldner, and Cahill}

Glucagon has recently been reported to affect concentrations of individual plasma amino acids in man (31) and animals (32). The present findings confirm the observed effect of a decrease in levels of most amino acids and of previous studies in which total amino acids (as alpha-amino nitrogen) were measured (33). These investigations uniformly employed large doses of glucagon.

That a primary site of the amino acid lowering effect is the liver is suggested by the data referred to above, indicating increased urea nitrogen excretion in the studies with higher glucagon doses. Since no change in the "unmeasured" urine nitrogen component was observed, it is unlikely that a substantial increase in renal amino acid excretion could account for the hypoaminoacidemia. Studies by Kibler, Taylor, and Meyers in man (34) and by Shoemaker and Van Itallie in dogs (35) have shown increased splanchnic extraction of alphaamino nitrogen after glucagon. These in vivo experiments do not account for possible heterogeneity of hepatic response to glucagon with respect to individual amino acids, nor to the induced insulin response exert- 
ing a peripheral effect (26) in reducing circulating amino acid levels. That the former is important has recently been demonstrated by Mallette, Exton, and Park (36) with physiological glucagon doses in isolated perfused livers of fed rats. Indeed, the following four different patterns of response were shown: $(a)$ uptake of histidine, the only amino acid with resting uptake or output, was unchanged by glucagon; $(b)$ uptake of glycine, alanine, phenylalanine, arginine, and lysine was stimulated; $(c)$ output of leucine, isoleucine, and valine resulted; $(d)$ tyrosine, methionine, and tryptophan handling did not change. Furthermore, the alterations in extracellular and intracellular concentration of free amino acids suggested that the observed response resulted from one or a combination of the following mechanisms: $(a)$ increased intracellular utilization, for example, for gluconeogenesis, (b) stimulation of inward transport, and (c) intracellular production, as from proteolysis.

The most striking difference between these findings in vitro and those of the present study is that, with no important exception, all circulating amino acids measured decreased in concentration at least transiently. This may be accounted for by one or more of three possibilities: $(a)$ species differences, $(b)$ difference in the dose levels administered, or (c) presence of other responses in vivo which might obscure a similar effect in hepatic proteolysis and hepatic production of certain amino acids (36).

Levels of glucagon in the portal vein in the postabsorptive state are probably $500-800 \mu \mu \mathrm{g} / \mathrm{ml}$, as estimated from values determined in prancreaticoduodenal veins of dogs (15), which have similar peripheral vein concentrations to those in man. Thus, in order that peripheral vein levels double (as observed in early fasting), it would be anticipated that portal vein concentrations would increase at least twofold. The current studies employing $1 \mathrm{mg} / 24 \mathrm{hr}$ showed hyperglycemia and stimulated gluconeogenesis with peripheral levels of glucagon of $700-1400 \mu \mu \mathrm{g} / \mathrm{ml}$. This suggests that the observed elevations in endogenous peripheral glucagon levels early in fasting reflect levels in portal blood which would be expected to stimulate hepatic gluconeogenesis, further confirming an important regulatory role in fasting.

The studies employing $0.1 \mathrm{mg}$ of glucagon per $24 \mathrm{hr}$ demonstrate the exquisite sensitivity of the amino acid lowering effect. Kaminsky and colleagues (37), infusing 1.5 times this amount into postabsorptive man, recently showed highly significant increases in plasma cyclic $3^{\prime}, 5^{\prime}$-adenosine monophosphate concentration, further evidence of an effect at low levels. In light of the high concentrations of glucagon to which the liver is always exposed as compared with the periphery, the increment in the $0.1 \mathrm{mg} / 24 \mathrm{hr}$ infusions is proportionally greater at the periphery $(75 \%)$ than at the liver (probably less than 20\%). This, in addition to the absence of increased urea excretion, suggests that an extrahepatic site may contribute to the hypoaminoacidemia. Whatever the locus of this effect, its demonstration at physiologic levels clearly implicates glucagon as an important regulator of amino acid metabolism.

Finally, the levels of glucagon obtained with the two lower rates of infusion confirm the accuracy of the glucagon determinations. Distribution of the infused hormone into the extracellular fluid with an estimated half-time of disappearance of 10-15 min would be expected to induce the magnitude of rise observed. The endogenous levels reported are thus validated as bona fide estimates of pancreatic glucagon.

\section{ACKNOWLEDGMENTS}

We wish to express our appreciation to Miss Patricia Barlas and to Mrs. Dzidra Rumba, Adacie Allen, Velta Ramolins, and Anna Karras and to Mr. Lynn Lowe for their dedicated technical assistance; to Dr. Ray Gleason for valuable suggestions regarding the statistical analyses; and to the nurses and staff of The Clinical Center at the Peter Bent Brigham Hospital.

This work was supported in part by U. S. Public Health Service grants, AM-05077, AM-09584, AM-09748, AM-02700, and FR-31, and the John A. Hartford Foundation, Inc., New York.

\section{REFERENCES}

1. Mialhe, P. 1958. Glucagon, insuline et régulation endocrine de la glycémie chez le canard. Acta Endocrinol. 28 (Suppl. 36) : 134.

2. Mikami, S.-I., and K. Ono. 1962. Glucagon deficiency induced by extirpation of alpha islets of the fowl pancreas. Endocrinology. 71: 464.

3. Unger, R. H., A. M. Eisentraut, M. S. McCall, and L. L. Madison. 1962. Measurements of endogenous glucagon in plasma and the influence of blood glucose concentration upon its secretion. J. Clin. Invest. 41: 682.

4. Assan, R., G. Rosselin, and J. Dolais. 1967. Effets sur la glucagonémie des perfusions et ingestions d'acides aminés. Journées Annuells de Diabetologie de l'Hotel Dieu. $7: 25$.

5. Benedict, F. G. 1915. A study of prolonged fasting. Carnegie Inst. Wash. Publ. 203.

6. Aguilar-Parada, E., A. M. Eisentraut, and R. H. Unger. 1969. Effects of starvation on plasma pancreatic glucagon in normal man. Diabetes. 18: 717.

7. Unger, R. H., A. Ohneda, E. Aguilar-Parada, and A. M. Eisentraut. 1969. The role of aminogenic glucagon secretion in blood glucose homeostasis. J. Clin. Invest. 48: 810.

8. Owen, O. E., P. Felig, A. P. Morgan, J. Wahren, and G. F. Cahill, Jr. 1969. Liver and kidney metabo'ism during prolonged starvation. J. Clin. Invest. 48: 574.

9. Sokal, J. E., and E. Z. Ezdinli. 1967. Basal plasma glucagon levels of man. J. Clin. Invest. 46: 778.

10. Felig, P., O. E. Owen, J. Wahren, and G. F. Cahill, Jr. 1969. Amino acid metabolism during prolonged starvation. J. Clin. Invest. 48: 584. 
11. Pagliara, A. S., and A. D. Goodman. 1969. Elevation of plasma glutamate in gout. Its possible role in the pathogenesis of hyperuricemia. N. Engl. J. Med. $281: 767$.

12. Unger, R. H., E. Aguilar-Parada, W. A. Müller, and A. M. Eisentraut. 1970. Studies of pancreatic alpha cell function in normal and diabetic subjects. J. Clin. Invest. 49: 837.

13. Cahill, G. F., Jr., M. G. Herrera, A. P. Morgan, J. S. Soeldner, J. Steinke, P. L. Levy, G. A. Reichard, Jr., and D. M. Kipnis. 1966. Hormone-fuel interrelationships during fasting. J. Clin. Invest. 45: 1751.

14. Snedecor, G. W. 1956. Statistical Methods. Applied to Experiments in Agriculture Biology. Iowa State College Press, Ames, Iowa. 5th edition.

15. Unger, R. H., A. Ohneda, E. Aguilar-Parada, and A. M. Eisentraut. 1969. The role of aminogenic glucagon secretion in blood glucose homeostasis. J. Clin. Invest. 48: 810.

16. Lambert, A. E., and J. J. Hoet. 1965. Diurnal pattern of plasma insulin concentration in the human. Diabetologia. 2: 69 .

17. Faiman, C., and J. A. Moorhouse. 1967. Diurnal variation in the levels of glucose and related substances in healthy and diabetic subjects during starvation. Clin. Sci. (London). 32: 111.

18. Feigin, R. D. 1969. Blood and urine amino acid aberrations. Physiologic and pathological changes in patients without inborn errors of amino acid metabolism. Amer. J. Dis. Child. 117: 24.

19. Young, V. R., M. A. Hussein, E. Murray, and N. S. Scrimshaw. 1969. Tryptophan intake, spacing of meals, and diurnal fluctuations of plasma tryptophan in men. Amer. J. Clin. Nutr. 22: 1563.

20. Unger, R. H., A. M. Eisentraut, and L. L. Madison. 1963. The effects of total starvation upon the levels of circulating glucagon and insulin in man. J. Clin. Invest. 42: 1031 .

21. Mackrell, D. J., and J. E. Sokal. 1969. Antagonism between the effects of insulin and glucagon on the isolated liver. Diabetes. 18: 724.

22. Lewis, S. B., J. H. Exton, R. J. Ho, and C. R. Park. 1970. Dose responses of glucagon $\left(2 \times 10^{-12}\right.$ to $1 \times 10^{-6}$ $\mathrm{M}$ ) in the perfused rat liver. Fed. Proc. 29: 379. (Abstr.)

23. Felig, P., E. Marliss, T. Pozefsky, and G. F. Cahill, Jr. 1970. Amino acid metabolism in the regulation of gluconeogenesis in man. Amer. J. Clin. Nutr. 23: 986.
24. Felig, P., T. Pozefsky, E. Marliss, and G. F. Cahill, Jr. 1970. Alanine: key role in gluconeogenesis. Science (Washington). 167: 1003.

25. Felig, P., E. Marliss, and G. F. Cahill, Jr. 1969. Plasma amino acid levels and insulin secretion in obesity. $N$. Engl. J. Med. 281: 811.

26. Pozefsky, T., P. Felig, J. D. Tobin, J. S. Soeldner, and G. F. Cahill, Jr. 1969. Amino acid balance across tissues of the forearm in postabsorptive man. Effects of insulin at two dose levels. J. Clin. Invest. 48: 2273.

27. Salter, J. M., C. Ezrin, J. C. Laidlaw, and A. G. Gornall. 1960. Metabolic effects of glucagon in human subjects. Metab. (Clin. Exp.) 9: 753.

28. Goodman, A. D., R. E. Fuisz, and G. F. Cahill, Jr. 1966. Renal gluconeogenesis in acidosis, alkalosis, and potassium deficiency: its possible role in regulation of renal ammonia production. J. Clin. Invest. 45: 612 .

29. Hagen, J. H. 1961. Effects of glucagon on the metabolism of adipose tissue. J. Biol. Chem. 236: 1023.

30. Lefebvre, P. 1966. The physiological effect of glucagon on fat-mobilisation. Diabetologia. 2: 130.

31. Landau, R. L., and K. Lugibihl. 1969. Effect of glucagon on concentration of several free amino acids in plasma. Metab. (Clin. Exp.) 18: 265.

32. Bromer, W. W., and R. E. Chance. 1969. Zinc glucagon depression of blood amino acids in rabbits. Diabetes. 18: 748.

33. Bondy, P. K.., and L. R. Cardillo. 1956. The effects of glucagon on carbohydrate metabolism in normal human beings. J. Clin. Invest. 35: 494.

34. Kibler, R. F., W. J. Taylor, and J. D. Myers. 1964. The effect of glucagon on net splanchnic balances of glucose, amino acid nitrogen, urea, ketones, and oxygen in man. J. Clin. Invest. 43: 904.

35. Shoemaker, W. C., and T. B. Van Itallie. 1960. The hepatic response to glucagon in the unanesthetized dog. Endocrinology. 66: 260.

36. Mallette, L. E., J. H. Exton, and C. R. Park. 1969. Effects of glucagon on amino acid transport and utilization in the perfused rat liver. J. Biol. Chem. 244: 5724 .

37. Kaminsky, N. I., J. H. Ball, A. E. Broadus, J. G. Hardman, E. W. Sutherland, and G. W. Liddle. 1970. Hormonal effects on extracellular cyclic nucleotides in man. Clin. Res. 18: 528. 